\title{
Eukaryotic Translation Initiation Factor 4 Gamma 1
}

National Cancer Institute

\section{Source}

National Cancer Institute. Eukaryotic Translation Initiation Factor 4 Gamma 1. NCI

Thesaurus. Code C82963.

Eukaryotic translation initiation factor 4 gamma 1 (1600 aa, $176 \mathrm{kDa}$ ) is encoded by the human EIF4G1 gene. This protein is involved in recognition of the mRNA 5 ' cap, unwinding of the mRNA structure and recruitment of mRNA to the ribosome. 